\title{
The Fungicide Thiram may Disrupt Reproductive Cycle of Domestic Male Pigeon (Columba livia domestica) Subjected to a Long Photoperiod
}

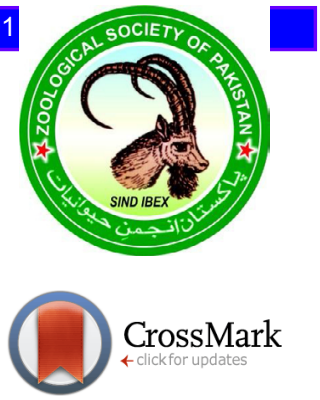

\author{
Souheila Slimani ${ }^{1, *}$, Sonia Hamouda ${ }^{1}$, Chahrazed Souadi ${ }^{1}$, Sara Silini ${ }^{2}$, \\ Cherif Abdennour ${ }^{2}$ and Leila Delimi ${ }^{3}$ \\ ${ }^{1}$ Department of Biology, Faculty of Sciences, University of 20 August 1955, Skikda \\ 21000, Algeria \\ ${ }^{2}$ Laboratory of Animal Ecophysiology, Department of Biology, University Badji \\ Mokhtar-Annaba, Annaba 23000, Algeria \\ ${ }^{3}$ Laboratoy of Anatomopathyology, EPS of Skikda 21000, Algeria
}

\begin{abstract}
A B S T R A C T
Fungicides are toxic chemicals, very much used in agriculture, but they are associated with the appearance of certain metabolic, carcinogenic, neurotoxic and fertility disorders. The objective of this work is to study the toxic effect of the dithiocarbamate "thiram $80 \%$ purity" on seasonal reproduction of male domestic pigeons Columba livia domestica, subjected to a long photoperiod (19L: 05D). The fungicide was orally administered at 5 and $10 \mathrm{mg} / \mathrm{Kg}$ body weight/day for 10 consecutive weeks. Testicular volume and weights were measured weekly, whereas semen quality, and histopathological profile were investigated at week 10.The obtained results reveal that under a long photoperiodthe sexual activity of the control lasted only 04 weeks, characterized by significant increase in the testicular volume, followed by spontaneous gonadal regressionup to week 10. Consequently, an azospermia and lack of germ cells in control birds was noticed, which confirm the testicular regression.In the treated groups, thiram delayed the refractory phase along the experimental period, but testicular weight were superior in the treated pigeons compared to the control during the last weeks. Treated pigeons had more dead spermatozoa compared to the control. Remarkably, abnormal spermatozoa were much higher in the group received 5mg than that of $10 \mathrm{mg}$. The histological profile revealed degenerative changes in testes of treated pigeons with elongated and irregular diameter of seminiferous tubules, degenerative of Sertoli cells, severe atrophy of Leydig cells and pronounced decrease in the interstitial space. However, in the treated groups the stages of spermatogenesis appear unaffected, accompanied withimmature and malformed spermatozoa in the lumen.To conclude, oral administration of thiram may affect the seasonal reproduction of pigeon by disturbing the histo-architecture of testes and sperm quality under long photoperiod. Such changes may be responsible for delayed refractory phase. The intact stages of spermatogenesis indicates that the thiramexposed pigeons were not in the refractoriness period.
\end{abstract}

Article Information
Received 21 September 2017
Revised 03 November 2017
Accepted 13 November 2017
Available online 02 August 2018
Authors' Contribution
SS, SH, SS and CS carried out the
experimental work. LD performed the
histological study. SS wrote discussion.
CA corrected the langusge of the
article.
Key words
Thiram, Pigeon, Photoperiod,
Seasonal reproduction, Semen quality.

\section{INTRODUCTION}

$\mathrm{T}$ hiram (tetramethyl thiuram disulfide, TMTD) belongs to the dithiocarbamate family of pesticide. It is widely used as a foliar treatment on fruits, vegetables, ornamentals and turf crops (Kunkur et al., 2007), and as a seed treatment to control seedling blights and a number of fungi that cause "damping off" in seedlings (Lohse et al., 2015). Also, it is used by humans in the

\footnotetext{
* Corresponding author: shsouheila@yahoo.fr 0030-9923/2018/0005-1693 \$ 9.00/0

Copyright 2018 Zoological Society of Pakistan
}

treatment of scabies and as a bactericide for skin disorders (Ceresera et al., 2001) and is used in rubber industry as an accelerator and a vulcanization agent (Grosicka et al., 2005).

In spite of its benefits, thiram poses a potential threat to people and to the environment (Lohse et al., 2015). Thiram is slightly soluble in water $\left(30 \mathrm{ppm}\right.$ at $\left.25^{\circ} \mathrm{C}\right)$, (Aulakh et al., 2005), this makes its elimination from the natural environment very difficult (Gupta et al., 2012). It is being a toxic substance for aquatic life; with an LC50 of less than 5 ppm for most of fish species (Sharma et al., 2003).

In the human body, Thiram is metabolized to 
give carbon disulfide, causing liver damage. Its group dithiocarbamate (DTC) reacts with sulfur- containing enzymes and co-enzymes, leading to blockage of their catalytic activity and causing cellular metabolism perturbation (Sharma et al., 2003). Also, due to their DTC group, thiram forms easily complexes with metals and exhibits a specific redox behavior at mercury and gold electrodes (Hernandez-Olmos, 2000). Thiram is also, known as an inducer of allergic dermatitis and as an inhibitor of angiogenis, a stimulator of the eyes, skin, and respiratory tract. The dermal $\mathrm{LD}_{50}$ in rats is more than 2000g. Rakitsku et al. (2016) have revealed that workers in the rubber industry and hospital surgical staff who use rubber gloves showed skin lesions as hand eczema or dermatitis. However, Hakama and Kilpikari (1980) have reported an increased risk of stomach, lung, bladder and blood cancer in people working in the rubber industry. In addition to this, thiram has been found to be a mutagenic (Agrawal et al., 1997; Ardito et al., 1997) and a teratogenic agent (Robens, 1969).

Chronic exposures have been found to affect adversely reproductive function in both female rodents (Short et al., 1976) and birds (Weppelman et al., 1980; Wedig et al., 1968). Stoker et al. (1993) have reported that thiram disrupts the hormonal control of ovulation in female rats. It has been demonstrated that Thiram was found to inhibit dopamine B-hydroxylase (DBH), thereby affecting norepinephrine (NE) synthesis which plays an important role in the hypothalamic regulation of pituitary function (Lippmann and Lioyd, 1971). Zdzienicka et al. (1982) have confirmed that thiram induced sperm head abnormalities in mice. A remarkable increase in the frequency of chromosomal aberrations and abnormal sperms was observed in treated mice exposed to thiram (Hema-Prasad et al., 1987). Another study performed on germ cells of Swiss albino males had showed by 80 $200-320 \mathrm{mg} / \mathrm{Kg}$ body of thiram. Though, pregnant mice given oral doses of thiram $10-30 \mathrm{mg} /$ animal from day 5 to 15 of during pregnancy had delivered fetuses and pups malformed, characterized by cleft palates, micrognathia, wavy ribs and distorted bones (Short et al., 1976).

Furthermore, some farmers used seeds treated with pesticides to avoid the need for spraying after plantation (Prosser et al., 2006). But, treated seeds may put granivors farmland birds at risk. In consequence, birds' mortality related to treated seed ingestion in several cases was reported (Stanley and Bunyan, 1979).

In view of the lack of information concerning the effect of thiram on pigeon reproduction, the current study has been undertaken to investigate the possible effects of thiram on reproductive cycle of domestic male pigeon (Columba livia domestica).

\section{MATERIALS AND METHODS}

Chemicals and dose selection

Thiram (tetramethylthiuram disulfide, CAS 137-268 ) chemical purity $80 \%, 5.5 \%$ surface additives and about $14.5 \%$ kaolin, was supplied by Sigma-Aldrich. Although in the literature the bird exposure dose were variable from 670 to $2800 \mathrm{mg} / \mathrm{Kg}$, a dose of 5 and $10 \mathrm{mg} / \mathrm{kg} /$ day, have been chosen in this experiment.

\section{Animals}

Male pigeon (Columba livia domesica), with average body weight of 200-250 g were acquired from Skikda (North-East of Algeria) at the end of February. Pigeons were kept in metal cages measuring $100 \times 100 \times 100 \mathrm{~cm}$, with six birds per cage. The cages were placed inside light-controlled rooms. Food (chick crumbs) and water were provided ad libitium. Birds were divided into three groups of 6 individuals each, where the first group was used as a control, but the second one has received orally 5 $\mathrm{mg} / \mathrm{Kg} /$ day of thiram. However, third group was given 10 $\mathrm{mg} / \mathrm{Kg} /$ day of thiram. All groups were held under artificial photoperiod of (19L:5D) by using electrical clock of 72 watts.

\section{Laparotomy and blood sampling}

Gonadal development was assessed by laparotomy at intervals of approximately 15 days. The gonads were examined through a small incision in the body wall between the last two ribs, after anesthetizing the incision with viscous lidocain. The dimensions of the left testis was measured to the nearest $0.5 \mathrm{~mm}$. Testicular volume was calculated as $V=4 / 3 \pi \mathrm{a} 2 \mathrm{~b}$; where, $\mathrm{a}$ is half the width and $\mathrm{b}$ is half the length (long axis).

\section{Semen quality}

After 10 weeks of experiment, pigeons were sacrificed; their testes were dissected out and weighed. The epididymis was carefully separated from the testis. $1 \mu \mathrm{l}$ of sperm was added to $49 \mu 1$ of physiological water $\mathrm{NaCl} 0.9 \%$. The sperm suspension was examined within 5 min after their isolation from epididymis. Both motile and immotile spermatozoa were then counted. Results were finally expressed as percent

For the evaluation of the sperm morphology, the diluted sperm was stained with $1 \%$ eosin after $2 \mathrm{~min}$ as explained (Narayana et al., 2002). Briefly, the sperms in the smears were visualized under $40 \times$ or oil immersion objectives and any abnormalities of either heads or tails were noted.

\section{Histology}

After decapitation, testes were immediately fixed 
in Bouin's fluid for $24 \mathrm{~h}$, hydrated in alcohol grades and cleared in toluene prior to embedding in paraffin wax. Sections of $5 \mu \mathrm{m}$ thick were cut by microtome, stained with haematoxylin and Eosin and mounted on diesterase phthalate xylene.

\section{Statistical analysis}

Data wes expressed as mean \pm SEM. Statistical analysis was performed using one-way analysis of variance (ANOVA) followed by Student's t test to assess significant differences among treatment groups. All statistical analyses were performed using Minitab version 16.

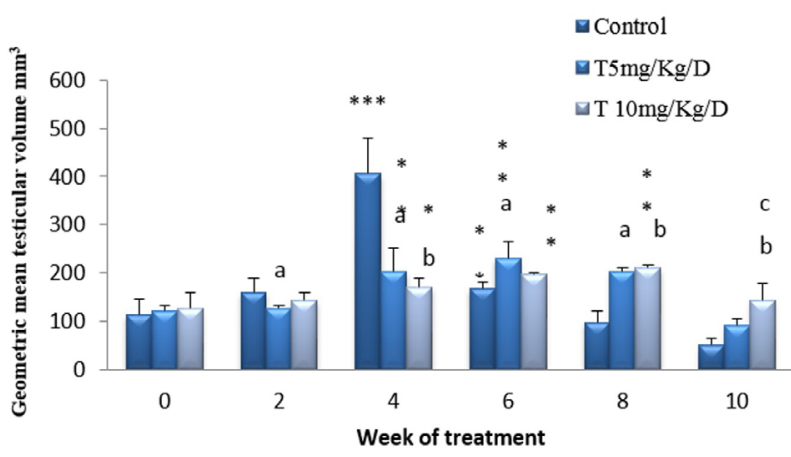

Fig. 1. Variation of the mean testicular volume $(\mathrm{m} \pm \mathrm{SE})$ of male pigeons (Columba livia domestica) subjected to a long photoperiod (19L:05D) and exposed to thiram $(\mathrm{n}=6)$. a, difference between control and $\mathrm{D} 1 ; \mathrm{b}$, difference between control and D2; c, difference between D1 and D2.

\section{RESULTS}

\section{General toxicity}

No mortality was observed during the experimental period. However at dose of $10 \mathrm{mg} / \mathrm{Kg}$, certain symptoms of intoxication as weakness and diarrhea were observed in most birds.

\section{Changes in testicular volume}

Changes in gonadal size measured during the present study are shown in Figure 1. At the beginning of the experiment, birds had a mean testicular size of $120.16 \pm$ $6.10 \mathrm{~mm}^{3}$. Control birds that were kept at long photoperiod throughout the experiment (19L:5D), had maintained fully reproductive cycle, characterized by significant $(\mathrm{p} \leq 0.05)$ increase in the testicular volume up to the fourth week, followed by spontaneous gonadal regression, with testes reaching a minimal size of $49.48 \pm 14.19 \mathrm{~mm}^{3}(\mathrm{p} \leq 0.01)$ by week 10 of the experiment. Treated groups had not showed any increase in testicular size along the experimental period. However, mean testes size were superior in the treated pigeons compared to the control at the end of the experiment;in which testes' volumes were 90.20 \pm 15.99 $\mathrm{mm}^{3}$ and $144.06 \pm 15.99 \mathrm{~mm}^{3}$ in treated pigeon at $5 \mathrm{mg}$ and $10 \mathrm{mg}$, respectively.

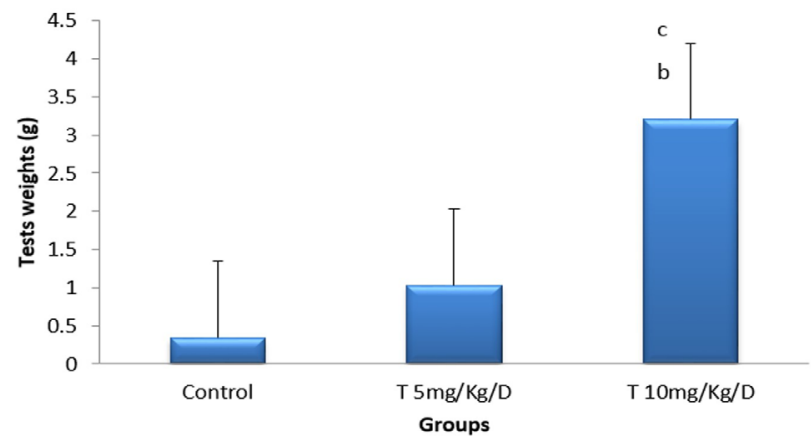

Fig. 2. Variation of the mean testicular weight at week $10(\mathrm{~m} \pm \mathrm{SE})$ of male pigeons (Columba liviadomestica) subjected to a long photoperiod (19L: 05D) and exposed to thiram $(n=6)$. a, difference between control and D1; $b$, difference between control and D2; c, difference between D1 and D2.
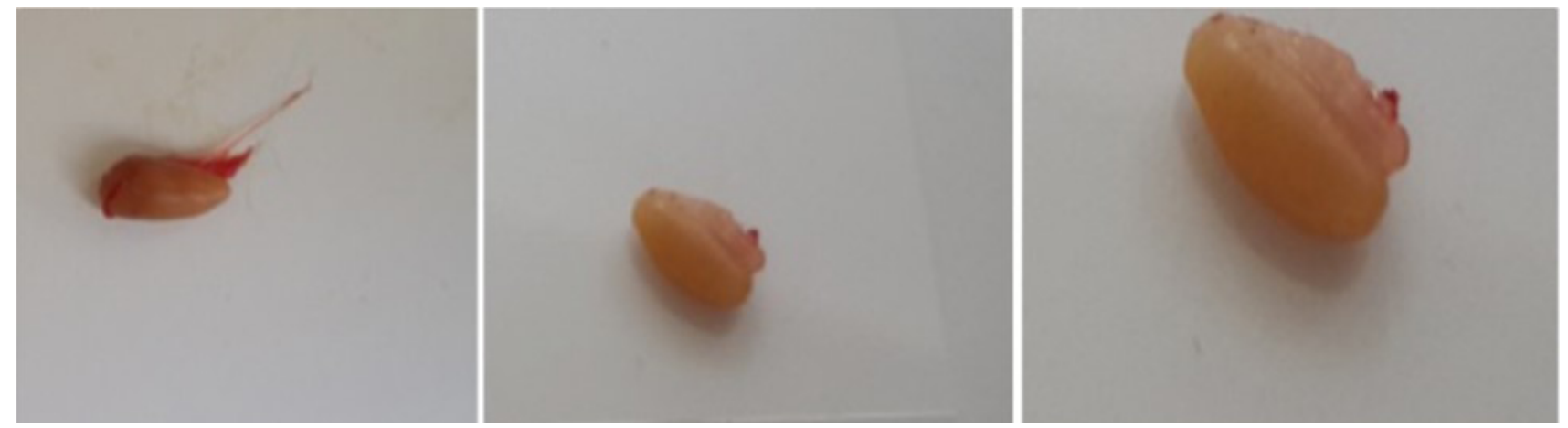

Fig. 3. Selected pictures of testes of male pigeons (Columba liviadomestica) at week 10 (C: control; D1, 5mg/Kg/D; D2, 10mg/ $\mathrm{Kg} / \mathrm{D})$ subjected to a long photoperiod (19L: 05D) and exposed to thiram ( $\mathrm{n}=6)$. 


\section{Testicular weight}

Figure 3 shows selected pictures of testes of male pigeons Columba livia domestica from the three groups (C, control; D1, dose 1; D2, dose2) exposed to long photoperiod.

The mean testicular weight of pigeons is shown in Figure 2, where control individuals had fully regressed gonads. There were a significant $(\mathrm{P}>0.01)$ differences between the mean testicular weight of the two treated groups of birds, but they were all, of course, considerably greater $(\mathrm{P}<0.01)$ than the testicular weight of the control.

\section{Sperm quality}

The sperm quality is shown in Table I. The obtained results revealed an azospermia in control pigeons after 10 weeks of experiment. However, the study showed a significant increase $(\mathrm{P}<0.001)$ of the dead spermatozoa in the treated pigeons. An increase in sperm abnormalities $(\mathrm{P}<0.05)$ in treated pigeon at $5 \mathrm{mg} / \mathrm{Kg} / \mathrm{day}$ and $(\mathrm{P}<0.01)$ in treated pigeon at $10 \mathrm{mg} / \mathrm{Kg} /$ day (Table I). The abnormal spermatozoawas inversely related to the dose, where the percentage of abnormal sperm was $74.6 \%$ and $33.6 \%$ at 5 $\mathrm{mg}$ and $10 \mathrm{mg}$, respectively (Table I). The abnormalities were in the head, neck and tail region of the spermatozoa. Thus, tail abnormalities are superior thanthat of the head in both treated pigeons.

\section{Histopathological studies}

The testis of control pigeon (Fig. 4) exhibited regular seminiferous tubules with a lack of successive stages of spermatogenesis and the absence of spermatozoa in the lumen of somniferous tubules marking thus, gonads regression and a refractoriness period. Figure 5 shows histology feature in the testis of pigeons received $5 \mathrm{mg} /$ $\mathrm{Kg} /$ day of thiram. The somniferous tubules begin to have an irregular diameter; lumen is more or less extended. The somniferous tubule showed successive stages of transformation of spermatogonia into spermatozoa which appear malformed. A slight decrease in Sertoli cells, and an atrophy of Leydig cells.

Table I.- Effects of Thiram on sperm quality in male pigeons (Columba livia domestica) subjected to long photoperiod (19L:5D) and treated for 70 days.

\begin{tabular}{|c|c|c|c|c|c|c|}
\hline \multirow[t]{2}{*}{ Groups } & \multicolumn{2}{|c|}{ Sperm vitality $(\%)$} & \multicolumn{2}{|c|}{ Sperm abnormalities (\%) } & \multicolumn{2}{|c|}{ Abnormalities (\%) } \\
\hline & Motile & Immotile & Normal & Abnormal & Head & Tail \\
\hline Control & 0 & 0 & 0 & 0 & 0 & 0 \\
\hline Thiram 5mg/Kg/D & $22 \pm 10.1^{\mathrm{a}^{*}}$ & $78 \pm 6.47^{\mathrm{a}^{* * *}}$ & $74.66 \pm 6.4^{\mathrm{a}^{* * *}}$ & $25.3 \pm 6.4^{\mathrm{a}^{*}}$ & $5 \pm 3^{a}$ & $95 \pm 5^{\mathrm{a}^{* * *}}$ \\
\hline Thiram 10mg/Kg/D & $20 \pm 6.32^{b^{*}, c}$ & $80 \pm 6.3^{b^{* * *}, \mathrm{c}}$ & $65.4 \pm 15.9^{\mathrm{b}^{* * *}, \mathrm{c}}$ & $33.6 \pm 17.5^{b^{* *}, c}$ & $11.2 \pm 13.2^{\mathrm{b}, \mathrm{c}}$ & $88.2 \pm 13.2^{\mathrm{b} * * *, c}$ \\
\hline
\end{tabular}

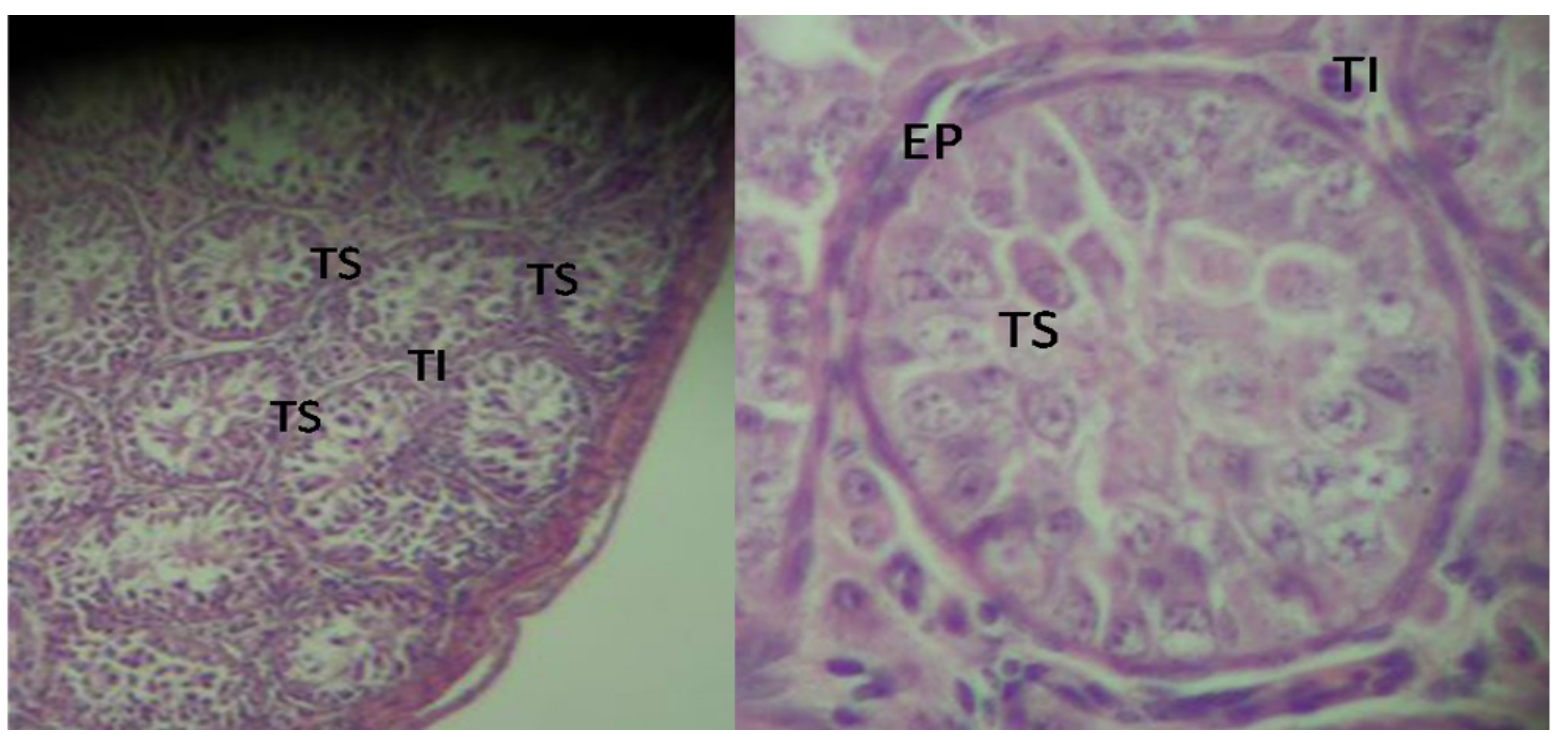

Fig. 4. The testis of control pigeons (Columba livia domestica) subjected to long photoperiod (19L:5D) for 10 weeks H\&E. Magnification $\mathrm{x} 10$ and $\mathrm{x} 40$. The histological profile showing azospermia and lack of spermatogenesis stage. TS, somniferous tubules; TI, interstitial tissue; EP, epithelium. 


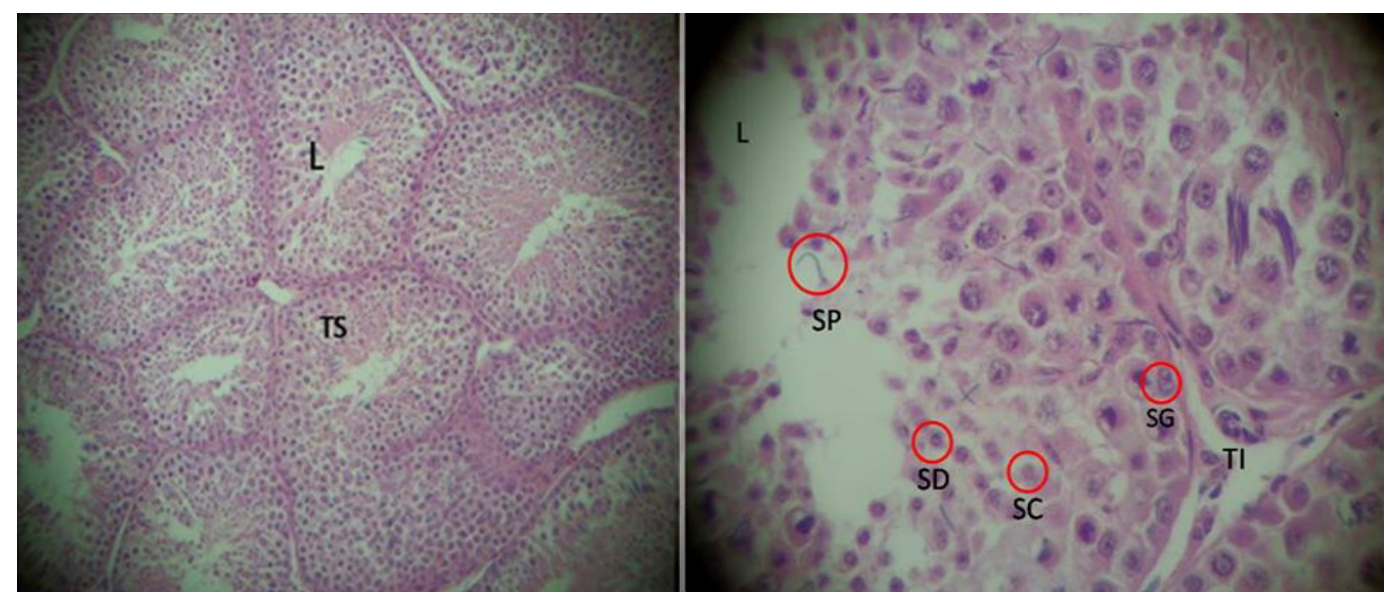

Fig. 5. Testis of pigeon (Columba livia domestica) exposed to Thiram $5 \mathrm{mg} / \mathrm{Kg} /$ day for 10 weeks and subjected to long photoperiod (19L:5D), H\&E. Magnification x10 and x40. L, lumen; Sp, spermatozoa; SG, spermatogonia; SC, spermatocyte; SD, spermatide. Degenerative in the histoarchitecture of testis are seen. Irregular somniferous tubules with all successive stages of spermatogenesis, some malformed spermatozoa in the lumen, slight decrease in Sertoli cell counts and a decrease in the interstitial spaces.

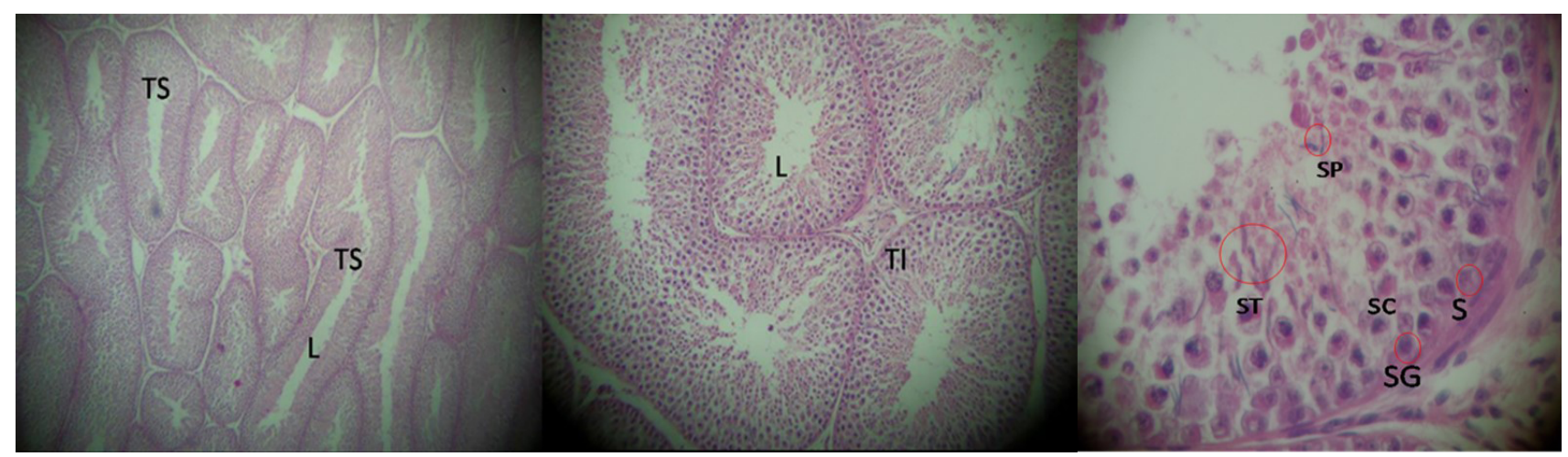

Fig. 6. Testis of pigeon (Columba livia domestica) exposed to Thiram at $10 \mathrm{mg} / \mathrm{Kg} /$ day after 10 weeks (H\&E. Magnification x10 and $\mathrm{x} 40$ ). L, lumen; Sp, spermatozoa; SG, spermatogonia; SC, spermatocyte; SD, spermatide; S, Sertoli cells. Acute degenerative in the histoarchitecture of testis characterized by elongated and irregular diameter of seminiferous tubules with all the successive stages of spermatogenesis. Deteriorating of Sertoli cells, a pronounced decrease in interstitial space and severe atrophy of Leydig cells.

Histological examination of the testes from $10 \mathrm{mg} / \mathrm{Kg} /$ day treated pigeons (Fig. 6) showed marked degenerative changes which include elongated and irregular diameter of seminiferous tubules with degenerative of Sertoli cells. The study showed that the stages of spermatogenesis appear unaffected. However, spermatozoa seem immature and malformed. Furthermore, a severe decrease in interstitial space and severe atrophy of Leydig cells was observed.

\section{DISCUSSION}

The data reported in this study demonstrate that in vivo exposure to the fungicide thiram dose-dependently impairs pigeon's reproductive functions, by altering gonadal growth. In birds, gonadal growth and regression are highly seasonal and relate to environmental factors such as food availability and the photoperiod length (Budki et al., 2008). Therefore, the day length has been well defined as the regulator of different metabolic and reproductive activities in many avian species (Hahn and Shackleton, 2008; Dixit and Singh, 2011). Since the work of Rowan (1929), it has been clear that the primary environmental factor used by birds to time reproduction is the annual changes in photoperiod. Birds have extraretinal photoreceptors which they use, in conjunction with a circadian clock, to measure photoperiod (Dawson et al., 2001; Kumar et al., 2004). Findings from this work indicate that under artificial photoperiod (19L:5D), 
birds maintained a fully reproductive cycle characterized by full mature testes at the $4^{\text {th }}$ week, followed by spontaneous gonadal regression. The physiological mechanism underlying the photo-stimulation is that an increase in photoperiod elevates the rate of secretion of gonadotrophin-releasing hormone $(\mathrm{GnRH})$, leading to elevated gonadotrophin secretion, and hence gonadal maturation such as luteinizing hormone $(\mathrm{LH})$ and follicule hormone (FSH), which in turn induce gonad growth and steroid hormone production (Wingfield and Farner, 1993). However, the administration of thiram at a rate of $5 \mathrm{mg} /$ $\mathrm{Kg} /$ day and $10 \mathrm{mg} / \mathrm{Kg}$ /day to male pigeons under long days for 10 weeks, has inhibited the development of testes, and disturb their reproductive cycle. It has been recorded a lower means in testes sizes during the experiment in treated birds compared to the control. At the physiological level, it is difficult to discuss the correlation between the inhibiting effect of pesticides and the reproductive cycle of birds, but it is possible is attributed to the mechanism of measure of photoperiod. Therefore they hadn't estimated the true photoperiod, and consequently all photoperiod would be regarded as being short (Wilson and Reinert, 1993). Thirame like dithiocarbamates have a potential to disrupt the endocrine system and may affect growth, metabolism, reproduction and behavior etc. disrupting gonadal and adrenal axes and thyroid function are documented by many authors (Diamanti-Kandarakis et al., 2009; Fraites et al., 2009; Pandey et al., 2017). In birds mixture of mancozeb and imidacloprid had distrupt the pituitary-thyroid axis (Pandey and Mohanty, 2015). It is possible that thiram have interfered with testis function and indirectly acted at the level of hypothalamus or pituitary gland, or also directly on the testis as number of pesticides has showed testicular toxicity (Recio et al., 2005). Moreover, Goldman et al. (1990) have reported that the insecticide chlorodimeform may destroy endocrinologic homeostasis by suppressing GnRH release. It has also been reported that xenobiotics may affect reproductive function by direct insult to the cell populations within the gonads resulting in a feedback mechanism impairment of the hypothalamus and the pituitary (Pasqualini et al., 1990). Stoker et al. (1993) had reported that thiram is able to block the LH surge and inhibit subsequent ovulation if administered during a sensitive period prior to the initiation of the surge. In other study, Stoker et al. (1996) found that a single exposure to the fungicide thiram $(50 \mathrm{mg} / \mathrm{kg})$ during the critical period of proestrus prior to mating, resulted in a decrease in the rate of fetal development, as well as a reduction in the number of live fetuses and an increase in the number of resorptions on GD 20. Epidemiological and experimental studies support the hypothesis that high exposure to thiram provokes a significant fertility decrease and the qualitative impairment of offspring (Dănulescu et al., 2004).

The thyroid gland plays an essential role in the etiology of seasonal reproduction in birds (Boulakoud and Goldsmith, 1991). Thus, the active thyroid function is essential for this process, leading to the occurrence of refractoriness under long days. It was known that thiram and other xenobiotics causes tyroid dysfunction in animals and disrupt hypothalamo-pituitary axis (Pandey and Mohant, 2017).

Furthermore, the decreased sperm motility indicates the cytotoxic damage caused by thiram on germ cells, which was proportional to the dose-level. Sperm morphology also has an important relationship to sperm motility, where the reduced motility observed in this study is probably due to the morphological aberrations reported earlier (Kasker et al., 1994). Induced sperm abnormalities indicate point mutations in germ cells (Narayana et al., 2002), which should have triggered structural changes in cell organelles involved in head and tail formation, leading to sperm malformation. It has been reported that thiram induced sperm head abnormalities in mice (Zdzienicka et al., 1982). Furthermore, Hema-Prasad et al. (1987) have reported the mutagenic effects of thiram on germ cells of Swiss albino male. Pinar (2013) revealed that propineb may be a mutagen agent due to the observed rise in the frequency of mouse sperm abnormalities.

The weight of testes is largely dependent on the mass of differentiated spermatogenic cells, but the reduction of their weights, was consistent with the elimination of germ cells (Chapin and Lamb, 1994). In this study results have shown a decreased weight of control testes due to the refractoriness (Boulakoud and Goldsmith, 1991). However this study revealed, significant increaseof testicular weight with increasing thiram concentrations, which may be owed to elongated and enlarged lumen and interstitial spaces of the semineferous tubules. Other study revealed a testicular atrophy with damaged germinal epithelium, accompanied with reduced sperm motility and viability in male adult rats exposed to maneb and zineb (Lucier et al., 1977). It has been showed that the carbamate insecticide carbaryl has affected spermatogenic cells and caused leydig cells degeneration and altered serum testosterone and gonadotrophin levels (Shrivastava and Shrivastava, 1998). Slimani et al. (2014) have revealed that treatment of pigeons with propineb induced severe testicular lesion in which the siminiferous tubules were elongated and having slought germ cells at the level of their lumens with detachment of the seminiferous epithelium.

The presence of spermatozoa and theintact stages of spermatogenesis in the semineferous tubules of treated birds by 5 and $10 \mathrm{mg} / \mathrm{Kg} /$ day indicated that these pigeons were not in the refractoriness period. 


\section{CONCLUSION}

In conclusion, our results indicate that under a long daily photoperiod of (19L:5D), male domestic pigeon (Columba livia domestica) maintained a fully reproductive cycle characterized by full mature testes at the $4^{\text {th }}$ week, followed by spontaneous gonadal regression. Semen quality and the histopathological profile indicate an azospermia in control birds and confirm the refractoriness period in these birds. However, the administration of thiram at a rate of 5 and $10 \mathrm{mg} / \mathrm{Kg} /$ day to male pigeons under long days, has inhibited the development of testes, and disturbs their reproductive cycle. Treated pigeons had more dead and abnormal spermatozoa. The histological profile revealed degenerative changes in testes of treated pigeons with elongated and irregular diameter of seminiferous tubules, degenerative of Sertoli cells, severe atrophy of Leydig cells and pronounced decrease in the interstitial space. The intact stages of spermatogenesis indicates that the thiramexposed pigeons were not in the refractoriness period.

\section{Statement of conflict of interest}

Authors have declared no conflict of interest.

\section{REFERENCES}

Agrawal, R.C., Shukla, Y. and Mehrotra, N.K., 1997. Assessment of mutagenic potential of thiram. Fd. Chem. Toxicol., 35: 523-525. https://doi. org/10.1016/S0278-6915(97)00017-3

Ardito, G., Bigatti, P. and Lamberti, L., 1997. Increased frequencies of sister chromatid exchanges and micronuclei in 'in vitro' lymphocyte cultures treated with the fungicides thiram and ziram. Boll. Soc. Ital. Biol. Sper., 73: 1-7.

Aulakh, J.S., Malik, A.K. and Mahajan, R.K., 2005. Solid phase micro extraction-high pressure liquid chromatographic determination of nabam, thiram and azamethiphos in water samples with UV detection: Preliminary data. Talanta, 66: 266-270. https://doi.org/10.1016/j.talanta.2004.11.016

Boulakoud, M.S. and Goldsmith, A.R., 1991. Thyroxine treatment induces changes in hypothalamic gonadotrophin-releasing hormone characteristic of photo refractoriness in starlings (Sturnus vulgaris). Gen. Comp. Endocrinol., 82: 78-85. https://doi. org/10.1016/0016-6480(91)90298-K

Budki, P., Rani, S. and Kumar, V., 2008. Food deprivation during photosensitive and photo Refractory lifehistory stages affects the reproductive cycle in the migratory Red-headed Bunting (Emberiza bruniceps). J. exp. Biol., 212: 225-230. https://doi. org/10.1242/jeb.024190

Ceresera, C., Bogetb, S., Parvazc, P. and Revol, A., 2001. An evaluation of thiram toxicity on cultured human skin fibroblasts. Toxicology, 162: 89-101. https://doi.org/10.1016/S0300-483X(01)00347-X

Chapin, R.E. and Lamb, J.C., 1984. Effects of ethyleneglycolmonoethylether on various parameters of testicular function in the F344 rats. Environ. Hlth. Perspect, 57: 219-224. https://doi. org/10.1289/ehp.8457219

Dănulescu, E., Alexandrescu, I., Scutaru, B., Simirad, S. and Dănulescu, R., 2004. Reproductive effects of the fungicide thiram. Epidemiological and experimental studies. J. Prevent. Med., 12: 38-45.

Davydova, T.B., 1973. The effect of tetramethyl thiuram disulfide (thiram) inhaled on the estrous cycle and the reproductive function of the animals. Gig Sanit, 39: $85-87$.

Dawson, A., King, V.M., Bentely, G.E. and Ball, G.F., 2001. Photoperiodic control of seasonality in birds. J. Biol. Rhythms, 16: 365-380. https://doi. org/10.1177/074873001129002079

Diamanti-Kandarakis, E., Bourguignon, J.P., Giudice, L.C., Hauser, R., Prins, G.S., Soto, A.M., Zoeller, R.T. and Gore, A.C., 2009. Endocrine-disrupting chemicals: An endocrine society scientific statement. Endocr. Rev., 30: 293-342. https://doi. org/10.1210/er.2009-0002

Dixit, A.S. and Singh, N.S., 2011. Photoperiod as approximate factor in control of seasonality in the subtropical male tree sparrow, Passer montanus. Front. Zool., 8: 1. https://doi.org/10.1186/17429994-8-1

Filipe, O., Vidal, M., Duarte, A. and Santos, E., 2007. A solidphase extraction procedure for the cleanup of thiram from aqueous solutions containing high concentrations of humic substances. Talanta, 72: 1235-238. https://doi.org/10.1016/j. talanta.2007.01.005

Fraites, M.J.P., Cooper, R.L., Buckalew, A., Jayaraman, S., Mills, L. and Laws, S.C., 2009. Characterization of the hypothalamic-pituitary-adrenal axis response to atrazine and metabolites in the female rat. Toxicol. Sci., 112: 88-99. https://doi.org/10.1093/ toxsci/kfp194

Goldman, J.M., Cooper, R.L. and Laws, S.C., 1990. Chlordimeform-induced alterations in endocrine regulation within the male rat reproductive system. Toxicol. appl. Pharmacol., 104: 25-35. https://doi. org/10.1016/0041-008X(90)90279-4

Grosicka, E., Sadurska, B., Szumio, M., Grzela, T., Azarczyk, P., Niderla-Bieliska, J. and Rahden- 
Staro, I., 2005. Effect of glutathione depletion on apoptosis induced by thiram in Chinese hamster fibroblasts. Int. J. Immunopharmacol., 5: $1945-$ 1956. https://doi.org/10.1016/j.intimp.2005.06.017

Gupta, B., Rani, M. and Kumar, R., 2012. Degradation of thiram in water, soil and plants: A study by high-performance liquid chromatography. Biomed. Chromatogr., 26: 69-75. https://doi.org/10.1002/ bmc. 1627

Hahn, T.P. and Mac Dougall-Shackleton, S.A., 2008. Adaptive specialization, conditional plasticity, and phylogenetic history in the reproductive cue response systems of birds. Phil. Trans. R. Soc. Lond. B: Biol. Sci., 363: 267-286. https://doi.org/10.1098/ rstb.2007.2139

Hema-Prasad, M., Pushpavathi, K., Rita, P. and Reddy, P.P., 1987. The effect of thiram on the germ cells of male mice. Fd. Chem. Toxicol., 25: 709-711. https://doi.org/10.1016/0278-6915(87)90105-0

Hernandez-Olmos, M.A., Agui, L., Yanez-Sedeno, P. and Pingarron, J.M., 2000. Analytical voltammetry in low-permitivity organic solventsusing disk and cylindrical microelectrodes. Determination of thiram in ethyl acetate. Electrochim. Acta, 46: 289-296. https://doi.org/10.1016/S00134686(00)00584-3

Kasker, K., Franken, D.R., van der Horst, G., Oehninger, S., Kruger, T.F. and Hodgen, G.D., 1994. The ralationship between morphology, motility and zone pellucida binding potential of human spermatozoa. Andrologia, 26: 1-4.

Kumar, V., Singh, B.P. and Rani, S., 2004. The bird clock: A complex, multi-oscillatory and highly diversified system. Biol. Rhythms Res., 35: 121141. https://doi.org/10.1080/09291010412331313 287

Kunkur, V.K., Hunje, R., Biradar Patil, N.K. and Vyakarnhal, B.S., 2007. Effect of seed coating with polymer, fungicide and insecticide on seed quality in cotton during storage. Karnataka J. agric. Sci., 20: $137-139$.

Lippman, W. and Lioyd, K., 1971. Effect of tetramethylthiuram disulfide and structurally related compounds on the dopamine - $\beta$ - hydroxylase activity in the rat and hamster. Arch. Int. Pharmacodyn, 189: 348-357.

Lohse, R., Jakobs-Scho"nwandt, D., Vidal, S. and Patel, A.V., 2015. Evaluation of new fermentation and formulation strategies for a high endophytic establishment of Beauveria bassiana in oilseed rape plants. Biol. Contr., 88: 26-36. https://doi. org/10.1016/j.biocontrol.2015.05.002
Lucier, G.W., Lee, I.P. and Dixon, R.L., 1977. Effects of environmental agents on male reproduction. In: The testis, Vol. IV (eds. A.D. Johnson and W.R. Grames). Academic Press, New York. https://doi. org/10.1016/B978-0-12-386604-2.50027-2

Narayana, K., D’Souza, U.J.A. and Rao, K.P.S., 2002. Ribavirin-induced sperm shape abnormalities in Wistar rat. Mutat. Res., 513: 193-196. https://doi. org/10.1016/S1383-5718(01)00308-4

Pandey, S.P. and Mohanty, B., 2015. The neonicotinoid pesticide imidacloprid and the dithiocarbamate fungicide mancozeb disrupt the pituitary-thyroid axis of a wildlife bird. Chemosphere, 122: 227-234. https://doi.org/10.1016/j.chemosphere.2014.11.061

Pandey, S.P., Tsutsui, K. and Mohanty, B., 2017. Endocrine disrupting pesticides impair the neuroendocrine regulation of reproductive behaviors and secondary sexual characters of red munia (Amandava amandava). Physiol. Behav., 173: 17-22. https://doi.org/10.1016/j. physbeh.2017.01.030

Pasqualini, C., Sarrieau, A. and Dussaillant, M., 1990. Estrogen like effects of 712-dimethylbenz (a) antrancene on the female rat hypotalamo pituitary axis. J. Steriod Biochem., 36: 485-491. https://doi. org/10.1016/0022-4731(90)90092-7

Pinar, G.R., 2013. Abnormal sperm morphology in mouse germ cells after short-term exposures to acetamiprid, propineb, and their mixture. Arh. Hig. Rada Toksikol., 65: 47-56.

Prosser, P.J., Hart A.D.M., Langton, S.D., McKay, H.V. and Cooke, A.S., 2006. Estimating the rate of poisoning by insecticide-treated seeds in a bird population. Ecotoxicology, 15: 657-664. https:// doi.org/10.1007/s10646-006-0103-3

Rakitsku, V., Bereznyak, I., Sheveleva, T., Larkina, M., Tsataskis, A., 2016. Dermal thiram exposure of workers in rubber industry. Toxicol. Lett., 258: S210

Hakama, M. and Kilpikari, I., 1980. Cancer risk among rubber workers. J. Toxicol. environ. Hlth., 6: 1211.

Recio, R., Ocampo, G., Omez, G., Mor'an-Mart'inez, J., Borja-Aburto, V., Lopez-Cervantes, M., Uribe, M., Torres-Sanchez, L. and Cebrian, M.E., 2005. Pesticide exposure alters follicle-stimulating hormone levels in Mexican agricultural workers. Environ. Hlth. Perspect, 113: 1160-1163. https:// doi.org/10.1289/ehp.7374

Robens, J.F., 1969. Teratologic studies of carbaryl, diazinon, norea, disulfiram, and thiram in small laboratory animals. Toxicol. appl. Pharmacol., 15: 152-163. https://doi.org/10.1016/0041- 
008X(69)90143-4

Rowan, W., 1929. Experiments in bird migration, I. Manipulation of the reproductive cycle: Seasonal histological changes in the gonads. Proc. Boston Soc. Nat. Hist., 39: 115-208.

Sharma, V.K., Aulakh, J.S. and Malik, A.K., 2003. Thiram: Degradation, applications and analytical methods. J. environ. Monit., 5: 717-723. https://doi. org/10.1039/b304710e

Short, R.D., Russel, J.Q., Minor, J.L. and Lee, C., 1976. Developmental toxicity of ferric dimethyldithiocarbamate and bis (dimethylthiocarbamoyl) disulfide in rats and mice. Toxicol. appl. Pharmacol., 35: 83-94. https://doi. org/10.1016/0041-008X(76)90113-7

Shrivastava, S.M. and Shrivastava, V.K., 1998. Toxicological effects of carbaryl on testicular morphology and testosterone levels in musmusculus. Poll. Res., 17: 215-218.

Slimani, S., Boulakoud, M.S., Abdennour, C. and Gueddah, D., 2014. Antracol administration has disturbed the reproductive cycle of domestic pigeon Columba livia domestica. Adv. environ. Biol., 8: 82-91.

Stanley, P.I. and Bunyan, P.J., 1979. Hazards to wintering geese and other wildlife from the use of dieldrin, chlorfenvinphos and carbophenothion as wheat seed treatments. Proc. R. Soc. Lond. B: Biol. Sci., 205: 31-45. https://doi.org/10.1098/ rspb.1979.0047

Stoker, T.E., Goldman, J.M. and Cooper, R.L., 1993.
The dithiocarbamate fungicide thirame distrupts the hormonal control of ovulation in the female rat. Rep. Toxicol., 7: 211-218.

Stoker, T.E., Cooper, R.L., Goldman, J.M. and Andrews, J.E., 1996. Characterization of pregnancy outcome following thiram-induced ovulatory delay in the female rat. Neurotoxicol. Teratol., 18: 277-282. https://doi.org/10.1016/S0892-0362(96)90025-2

Wedig, J., Cowan, A. and Hartung, R., 1968. Some of the effects of tetramethylthiuram disulfide (TMTD) on reproduction of the bob- white quail. Toxicol. appl. Pharmacol., 12: 293- 297.

Weppelman, R.M., Long, R.A., van Iderstine, A., Taylor, J.E., Tolman, R.L., Peterson, L. and Olson G., 1980. Anti-fertility effects of dithiocarbamates in laying hens. Biol. Reprod., 23: 40-46. https://doi. org/10.1095/biolreprod23.1.40

Wilson, F.E. and Reinert, B.D., 1993. The thyroid and photoperiodic control of seasonal reproduction in American tree sparrows (Spizella arborea). J. comp. Physiol. B, 163: 563-573. https://doi. org/10.1007/BF00302115

Wingfield, J.C. and Farner, D.S., 1993. Endocrinology of reproduction in wild species. In: Avian biology (eds. D.S. Farner, J.R. King and K.C. Parkes). Academic Press, New York, pp. 163-327.

Zdzienicka, M., Hryniewicz, M. and Pienkowska, M., 1982. Thirame- induced sperm-head abnormalities in mice. Mut. Res., 102: 261-264. https://doi. org/10.1016/0165-1218(82)90135-5 